\title{
Impact of grazing on soil nutrients in a Pampean grassland
}

\author{
RAUL S. LAVADO, JORGE O. SIERRA, AND PATRICIA N. HASHIMOTO
}

\begin{abstract}
Authors are associate professor, assistant professor, and research fellow, Departamento de Suelos. Facultad de Agronomia, Universidad de Buenos Aires. Av. San Martin 4453, 1417 Buenos Aires. Argentina.
\end{abstract}

\begin{abstract}
Cattle exclusion induced dramatic changes in the plant community and modifications in nutrient cycling in grazed native grasslands of the Flooding Pampa (Argentina). The study was carried out to analyze the effect of grazing on the status and spatial variability of soil organic matter, nitrogen and phosphorus. Sampling was performed in the late summer and early spring. Geostatistical methods were used to study the spatial dependence of these soil properties.

Organic carbon (OC) and total nitrogen (TN) showed spatial structure only in the ungrazed area with a similar range of dependence (39 $\mathrm{m}$ and $36 \mathrm{~m}$ respectively). The occurrence of litter in this area lead to a large and spatially homogeneous $\mathbf{C}$ input to the soil, which would be the key factor of the spatial structure of organic carbon and total nitrogen. Mineral nitrogen content $\left[\left(\mathrm{NO}_{3}\right)^{-}\right)-\mathrm{N}+$ $\left.\left(\mathrm{NH}_{4}{ }^{+}\right)-\mathrm{N}\right]$ was higher in the ungrazed area on both sampling dates. The mineral $\mathbf{N}$ content showed a large short-range variability (nugget variation) independent of grazing history.

A significant decrease in the extractable P (Bray \& Kurtz \#1) in the grazed area was found. The extractable $P$ exhibited spatial structure only in the ungrazed area. However, its spatial pattern was different from those of organic carbon and total nitrogen: the range of dependence was higher $(57 \mathrm{~m})$ and the spatial structure exhibited a great irregularity. The differences between $\mathrm{C}, \mathrm{N}$, and $P$ variability were possibly related to their dynamics in the soil. No evidence of effects of animal excreta on nutrient content or spatial variability was found.
\end{abstract}

Key Words: grassland, organic carbon, nutrients, geostatistics, grazing.

Grazing affects the flux of nutrients in grasslands in different ways (trampling, consumption, excreta deposition, redistribution, export). The export of nutrients through calf production, is a major factor affecting soil nutrient status (Bauer et al. 1987). The literature dealing with the effects of grazing on soil organic matter and nutrient status is sometimes contradictory (Baner et al. 1987; Dix 1959; Dormaar et al. 1989; Graetz and Tongway 1986; Johnston et al. 1971; Risser et al. 1981; Smoliak et al. 1972; Thornley and Verberne 1989). It is a reflection of different environments, soils and grazing management. Therefore, a definitive description of soil organic matter and nutrient behaviour in grazed unfertilized grasslands is difficult to ascertain. Currently,

Manuscript accepted 23 Oct. 1995. increases of nitrogen and extractable phosphorus are related to excreta returns, and losses are related to net export of nutrients or erosion. These processes are a function of the stocking density and the initial nutrient status of the soils.

The Flooding Pampa region of Argentina is devoted mainly to the cattle industry on natural grasslands (Soriano 1991). Large native herbivores were scarce before the arrival of the Spaniards (Sala 1988); during the 19th century livestock production was established on large ranches, which are still found in the region. Grazing changed these grasslands (Sala 1988; Soriano 1991). Cumpared with ungrazed areas, a few large perennial tussocks were replaced by short and mid grasses, some annual grasses, exotic dicots and planophiles. In ungrazed exclosures, aerial biomass accumulated as standing dead and as litter (Sala 1988). In addition, Chaneton and León (1989) and Facelli et al. (1989) found that whilst in ungrazed exclosures the grassland comprised several defined patches of vegetation, in the grazing areas grazing impedes the spatial segregation of species and discrete patch differentiation. The effect of grazing on the nutrient status in these grasslands is unknown. It is possible that changes in the inputs and outputs of $\mathrm{C}$ and major nutrients in response to cattle exclusion markedly modify their spatial distribution pattern (Facelli and Pickett 1991; West et al. 1989). Chaneton et al. (1996) found that the $\mathrm{N}$ added from rainfall (around $7 \mathrm{~kg} / \mathrm{ha}$ year) is enough to cover $\mathrm{N}$ export for meat production. In contrast, a net continuous loss of $0.4 \mathrm{~kg}$ P/ha year occurs in these no P-fertilized grassland.

It has been postulated that good management of the natural forage resource is more sustainable than to change it to a seeded pasture (Soriano 1991). Among the management practices, the increase of nutrient availability of the grassland system is viewed as a key factor. Undoubted, fertilization and increasing stocking rates will have a large effect on the soil organic matter and nutrient dynamics. The analysis of soil variables sensitive to changes in the grazing system is an appropriate way to detect changes in the soil-plant relationship and help to avoid the unfavorable evolution of the system. On the other hand, a knowledge of the structure of the spatial dependency of soil organic matter and nutrients is important to carry out soil fertility studies and proper fertilization trials. Several workers have studied the spatial variability of soil properties using geostatistical methods (e.g. Bramley and White 1991; Davidoff and Selim 1988; Trangmar et al. 1985; Vieira et al. 1983). These methods allow the quantification of the spatial dependence among sampling points for a given variable. For instance, using geostatistical analysis, West et al. (1989) found that grazing markedly affected the pattern of spatial variability of $\mathrm{C}, \mathrm{N}$, and P. However, each of the nutrients showed a 
different spatial distribution as a consequence of differential effects of animal excreta.

The objective of this research was to investigate the effects of different grazing histories on both the amount and spatial variability of soil organic matter and major nutrients (N and $\mathrm{P}$ ). The study was performed in grazed and ungrazed areas because they represent 2 extreme conditions to determine how cattle management affect soil properties.

\section{Material and Methods}

\section{Area and Study Site Characteristics}

The "Flooding Pampa", located in the province of Buenos Aires (Argentina), is nearly flat. The region has a temperate and subhumid climate (mean temperatures are $8.5^{\circ} \mathrm{C}$ in winter and $21.5^{\circ} \mathrm{C}$ in summer and annual rainfall ranges from 850 to 1,050 $\mathrm{mm}$ ). Most years have periods of water excesses followed by periods of water deficits (Lavado and Taboada 1988). Soils remain water saturated in winter. Since runoff is almost negligible, any excess of rain-water accumulates on the soil surface causing waterlogging (Taboada and Lavado 1988). In excessively rainy years there are floods, which usually last from July to November (spring). In summer, water losses by evapotranspiration are usually very high and when rainfall is low, severe droughts occur. The area has a high water table, so halo-hydromorphic soils prevail (INTA 1990).

The study site was located at the middle of the region $\left(36^{\circ} 30^{\prime} \mathrm{S}\right.$, $58^{\circ} 30^{\prime} \mathrm{W}$ ), in a ranch near the town of Casalins, which has been engaged in cattle breeding since the end of the last century. The stock rate for the region is lower than 1.2 AUY/ha. The grassland community is characterized by Piptochaetium montevidense (Spreng.) Parodi, Eclipta bellidioides (Spreng.) Sch. Bip., Ambrosia tenuifolia Spreng., Briza subaristata Lam. and Mentha pulegium L., with the absence of native or exotic legumes (Burkart et al. 1990). The soil is the moderately saline phase of the General Guido series Typic Natraquoll (INTA 1990), that has never been ploughed. The plant community and the soil are representative of those from the center of the region (Burkart et al. 1990; Lavado and Taboada 1988). The soil profile includes: Ah horizon, loamy (clay $23.6 \%$ ), electrical conductivity episodically higher than $2 \mathrm{dS} \mathrm{m}$ and Sodium Adsorption Ratio (SAR) averaging 8; Bt horizon, clayey (clay 64\%) and a SAR averaging 25. The soil is well supplied with nutrients such as potassium and sulphur (Lavado and Taboada 1985; 1988).

\section{Soil Sampling and Laboratory Analysis}

Sampling was performed on 2 areas of the above described grassland community.

i) Grazed area: a 800 ha plot, continuously grazed for about 100 years with a stock rate around 0.5-1.0 AUY/ha. The grassland is representative of the present status of the natural vegetation in the studied region. Approximately $50 \%$ of the soil surface is bare.

ii) Ungrazed area: a 4-ha fenced exclosure located in the middle of the grazed field, where cattle grazing had been excluded for 13 years. The grasslands of the enclosure show some attributes resembling the ungrazed original system (Soriano 1991). The soil is fully covered by tussocks or litter. When the exclosure was established no perceivable differences were found with the rest of the plot.
In each area, soil samples were systematically taken every $3 \mathrm{~m}$ along a $150 \mathrm{~m}$ long transect (50 soil samples) (Fig 1). The Ah horizon ( $0.15 \mathrm{~m}$ depth) was sampled at each site, using a $8 \mathrm{~cm}$ diameter soil auger. Soil samples were taken on 2 dates representing the main seasonal extremes of environmental conditions: late summer (February), after the period of the summer drought (mid December, January), and early spring (October), after the usual winter period of water excess (mid July, August, September).

Soil samples were analyzed for organic carbon (OC) by the Walkley and Black method, total nitrogen (TN) by the Kjeldahl method, nitrate by the hydrazine reduction method, ammonium by the phenol-nitroprusiate method and extractable phosphorus (extractable-P) by the Bray and Kurtz \#1 method (Page et al. 1982). All results are expressed on an oven-dry $\left(105^{\circ} \mathrm{C}, 24\right.$ hour $)$ weight basis.

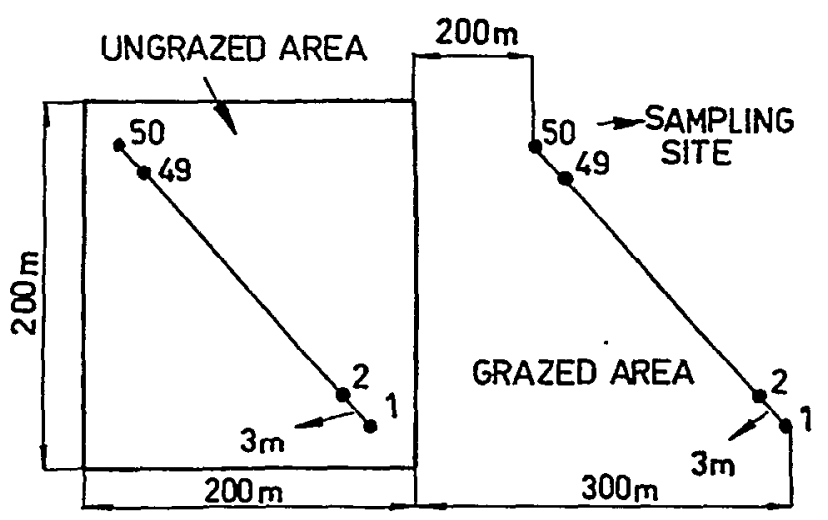

Fig. 1. Experimental design, showing distances among transects and among samples.

\section{Statistical and Spatial Variability Analysis}

Experimental data were subjected to classical statistical analysis to obtain descriptive statistics, means and standard deviation. The Kolmogorov-Smirnov method was used to test the frequency distribution of all the variables. Analysis of data using classical statistical methods requires independence between samples. If spatial correlation exists those methods are not appropiate for analysis and a geostatistical approach must be used (Vieira et al., 1983). To determine the degree of spatial correlation, sample semivariograms were constructed as described by Vieira et al. (1983). Cross-semivariograms were performed to analyze the spatial correlation between variables. The sample semivariance $(\hat{\gamma}(\mathrm{h})$ ) is given by

$$
\gamma(\mathrm{h}) \frac{1}{2 N(\mathrm{~h})} \Sigma\{\mathrm{z}(\mathrm{i})-\mathrm{z}(\mathrm{i}+\mathrm{h})]^{2}
$$

Where $z(i)$ is the value of the variable $z$ at sampling site $i$ and $z$ $(i+h)$ is the value of the variable $z$ at sampling site $i+h, h$ is the distance between sampling points. $N(h)$ is the number of pairs of observations separated by a distance or lag vector $h$. The sample semivariogram is plotted with $h$ as the abcissa and $p(h)$ as the ordinate, the $\gamma(h)$ points may be then fitted with theoretical models (e.g. linear, spherical, exponential). Characteristics of semivariograms, such as nugget ( $y$-intercept), sill (point of leveling off) and range (distance at which points become independent), are useful in explaining the spatial structure of a given variable. 
In the present study, when spatial structure was observed, the spherical model provided the best fit of the sample semivariance data. The equation is (Davidoff et al. 1986a):

$$
\begin{aligned}
& \gamma(\mathrm{h})=\mathrm{C}_{0}+\left(\mathrm{C}_{1}-\mathrm{C}_{0}\right)\left[\frac{3}{2} \frac{\mathrm{h}}{\mathrm{a}}-\frac{1}{2}\left(\frac{\mathrm{h}}{\mathrm{a}}\right)^{3}\right] 0 \leq \mathrm{h} \leq \mathrm{a} \\
& \gamma(\mathrm{h})=\mathrm{C}_{1} \quad \mathrm{~h} \geq \mathrm{a}
\end{aligned}
$$

Where $C_{0}$ is the nugget variance and represents the variability over distances smaller than the sampling distance and sampling error, " $a$ " is the range of dependence; " $\mathrm{C}_{1}$ " is the sill of the semivariogram.

The sample cross-semivariogram (Vieira et al. 1983) is estimated by:

$$
\gamma_{1,2}(h)=\frac{1}{2 N(h)} \sum\left(\left[z_{1}(i) z_{1}\left(i_{+} h\right)\right]\left\{z_{2}\left(i_{+} h\right)\right]\right)
$$

Where $z_{1}(i)$ and $z_{2}(i)$ are observations for variables $z_{1}$ and $z_{2}$ at location $i, Z_{1}(i+h)$ and $Z_{2}(i+h)$ are observations with separations of $h$ from $i$. If there is a positive spatial correlation between the variables, then $1,2(h)$ increases as a function of $h$ (or it decreases if the correlation is negative).

Semivariogram analysis requires stationarity of the variance; that is, constant expectancy of the variance of the observations along the transect line. Thus, the presence of a significant drift in the observations may give erroneous results. The occurrence of drift was examined using the experimental drift function $D$ established by Davidoff et al. (1986b).

$$
D(h, C)=[N(h, C)]^{-1} \sum\left[z_{c}\left(i_{+} h\right)\right]
$$

Where $\mathrm{C}$ is a complete set of all the possible pairs of observations, provided that each of them is used only once in the calculation of $D$ for each distance $h, z_{c}(i)$ and $z_{c}(i+h)$ are a pair of observations of lag $h$ in the complete set $C$ and $N(h, C)$ is the number of pairs in $C$. To determine the level of significance of $D$, the Davidoff et al. (1986b) test was used.

\section{Results}

The test of frequency distribution showed that all the variables were normally distributed, independent of the sampling date and grazing history (Table 1). There were no significant differences $(p<0.05)$ for organic carbon (OC) and total nitrogen (TN) between grazing conditions. The $\mathrm{C} / \mathrm{N}$ relationship (10.7) was normal for the soils of the region (INTA 1990; Lavado and Taboada $1885)$. The extractable $P$ was slightly but significantly $(p<0.05)$ lower in the grazed area.

Mineral nitrogen comprised about 3-8 times more $\mathrm{NH}_{4}{ }^{+}$than $\mathrm{NO}_{3}$ - (Fig. 2), a common ratio found in humid and temperate grassland soils (Clark and Paul, 1970). On both sampling dates, the mineral nitrogen content $\left[\mathrm{NO}_{3}{ }^{-}-\mathrm{N}+\mathrm{NH}_{4}{ }^{+}-\mathrm{N}\right]$ was higher in

Table 1. Organic Carbon, Total Nitrogen, and Extractable phosphorus in grazed and ungrazed grassland. Means and coefficients of variation.

\begin{tabular}{lccc}
\hline Treatment & & \multicolumn{2}{c}{ Variables $^{2}$} \\
\cline { 3 - 4 } & OC & TN & P \\
\hline Non-grazed & $3.05(\%)$ & $(\%)$ & $(\mathrm{mg} / \mathrm{kg})$ \\
Grazed & $3.09(19)$ & $0.275(18)$ & $5.2(27)$ \\
\end{tabular}

'Each value is the average of the 2 sampling date $(n=50)$, because no significant differences $(p<0.05)$ between sampling dates were found. Coefficient of variation $(\%)$ are shown in brackets.

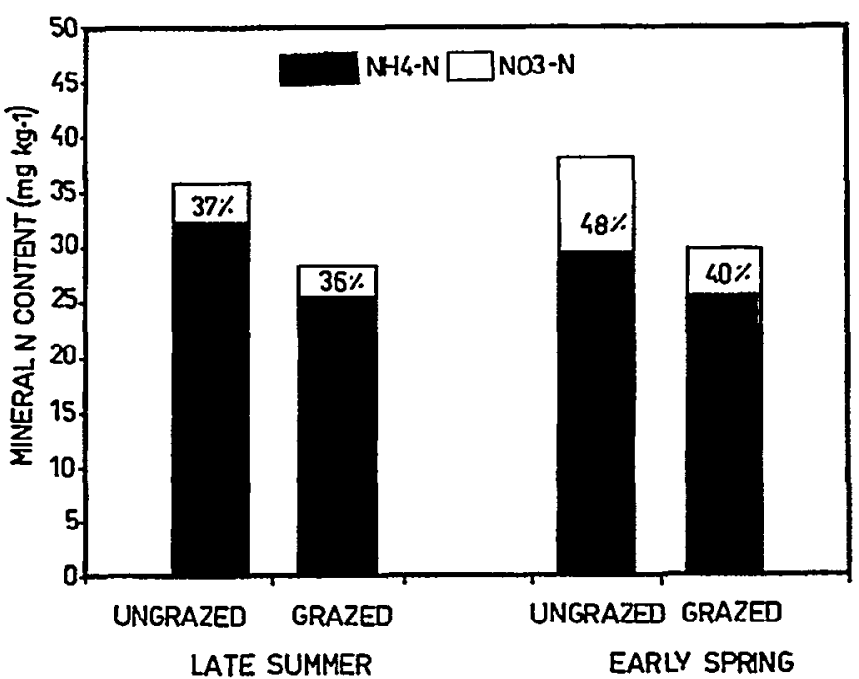

Fig. 2. Soil mineral $\mathbf{N}$ content in the ungrazed and grazed areas, for both sampling dates. The number within the square compartments are the coefficient of variation $(n=50)$. See text for statistical comparison.

the ungrazed area. This $\mathrm{N}$ pool was the most variable soil parameter. It is well known that local soil variations produce a great spatial variation in nitrate and ammonium content (Biggar 1978). The soil water content in the late summer was low $(11 \% \mathrm{w} / \mathrm{w})$, showing no difference between treatments. In early spring the water content was significantly higher in the ungrazed treatment $(16.3 \% \mathrm{w} / \mathrm{w})$ as compared with the grazed treatment $(10.8 \%$ w/w).

Under grazing conditions, and for both sampling dates, all the variables had pure nugget variation (Vieira et al. 1983) (Fig. 3). That is, the observations for all the variables were independent at the scale of sampling used in this study. From these results it may be assumed that short-range variability $(<3 \mathrm{~m})$ is the major cause of spatial variability in the grazing area.

Pure nugget variation was also observed for $\mathrm{NO}_{3}-\mathrm{N}, \mathrm{NH}_{4}-\mathrm{N}$, $\left(\mathrm{NO}_{3}+\mathrm{NH}_{4}\right)-\mathrm{N}$ and water content in the ungrazed treatment. However, in this area OC, TN, and extractable P had spatial structure on both sampling dates. If the semivariograms of each sampling date are approximately equal to sill and range of dependency, an average semivariogram may be calculated for each variable having spatial structure (Miller et al. 1988). Sill and range values did not strongly differ between sampling dates (Table 2), thus 1 average semivariogram was computed for each variable as proposed by Nash et al. (1988) (Fig. 4). The sill was reached at 13 lags $(39 \mathrm{~m})$ for $\mathrm{OC}, 12$ lags $(36 \mathrm{~m})$ for TN and 19 lags $(57 \mathrm{~m})$ for extractable $P$. Nugget variation, as obtained from the y-intercept (Vieira et al. 1983; Davidoff and Selim 1988) rep-

\begin{tabular}{|c|c|c|c|c|c|c|}
\hline \multirow{3}{*}{$\begin{array}{l}\text { Sampling } \\
\text { date }\end{array}$} & \multicolumn{6}{|c|}{ Variable } \\
\hline & \multicolumn{2}{|c|}{$T N$} & \multicolumn{2}{|c|}{$\mathrm{OC}$} & \multicolumn{2}{|c|}{$\mathbf{P}$} \\
\hline & $a^{1}$ & sill $^{2}$ & a & sil & a & sill \\
\hline 1 & 17 & 0.0026 & 14 & 0.43 & 22 & 2.5 \\
\hline 2 & 13 & 0.0023 & 13 & 0.38 & 18 & 1.8 \\
\hline
\end{tabular}

Table 2. Parameters of the semivariograms for Organic Carbon, Total Nitrogen, and Extractable phosphorus, in the non-grazed treatment for both sampling dates.

${ }^{1}$ The range $a$ is expressed in lag (1 lag $=3 \mathrm{~m}$ )

${ }^{2}$ Sill is expressed in the same units as the respective variance. 

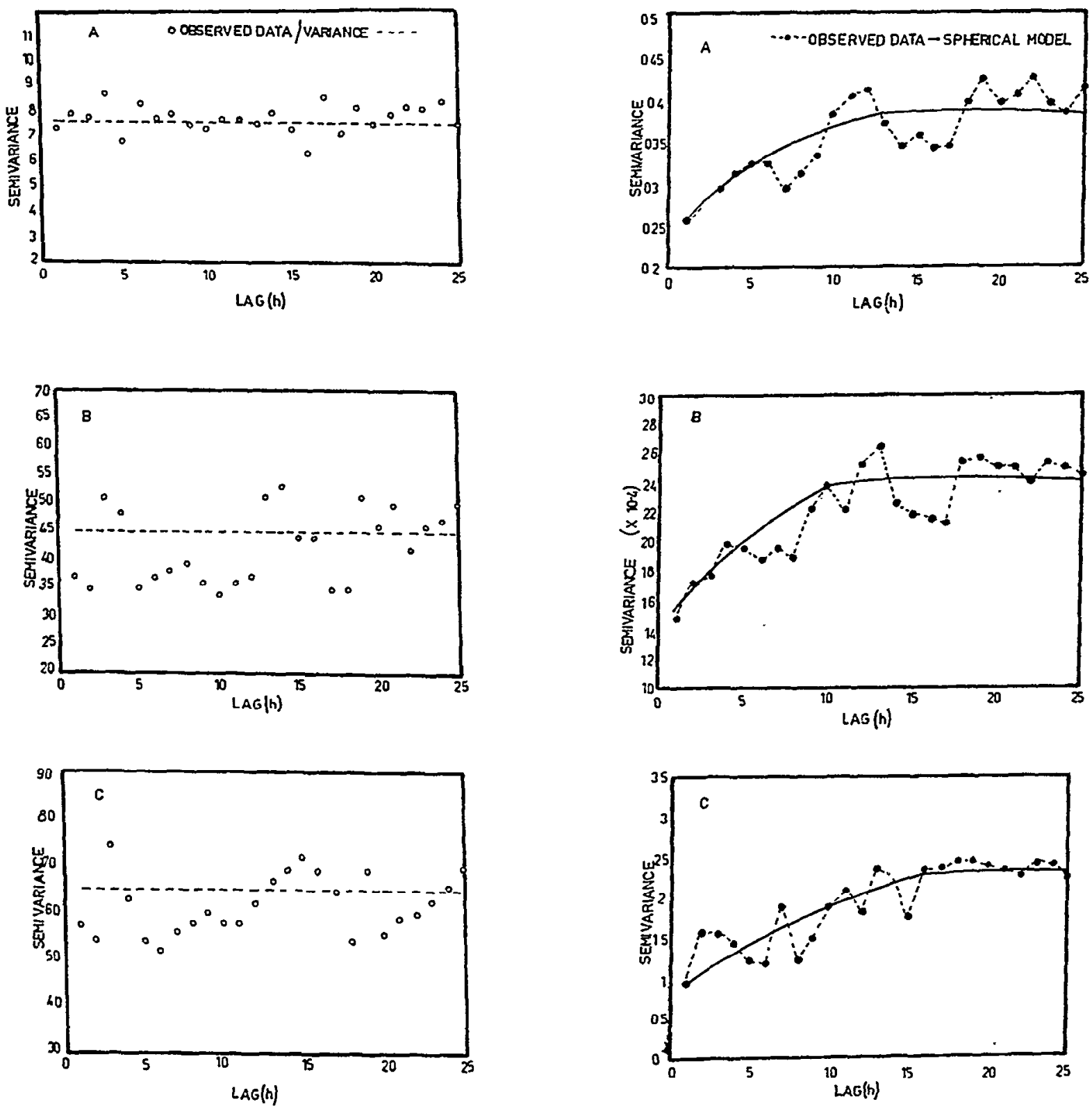

Fig. 3. Semivariograms with pure-nugget variation: a) $\mathrm{NO}_{3}-\mathrm{N}$; b) $\mathrm{NH}_{4}-\mathrm{N}$; and c) $\left(\mathrm{NO}_{3}+\mathrm{NH}_{4}\right)-\mathrm{N}$ corresponding to the second sampling date in grazed area $(1 \mathrm{lag}=3 \mathrm{~m})$.

resented $58 \%$ of the total variation of $\mathrm{OC}, 54 \%$ of TN and $42 \%$ of the extractable $P$. The semivariograms of $O C$ and TN showed dips at similar distances ( 7 and 15 lags approximately, Figs. 4 a and $4 \mathrm{~b}$ ). The occurrence of such dips might indicate a trend or a periodic behaviour or both (Davidoff et al. 1986a; 1986b). However, the test performed to verify this (Eq. 4) indicated that neither $\mathrm{OC}$ nor TN showed the presence of trends in the original data.

Note the spatial correlation of $\mathrm{OC}, \mathrm{TN}$, and extractable-P in the ungrazed area. This implies that the estimated variance of these variables is biased because the assumption of independence was violated. This is not the case in the grazed area because of the lack of any spatial dependence. According to Vieira et al. (1983), the sill of the semivariograms is approximately equal to the sam-

Fig. 4. Average semivariograms for ungrazed area: a) organic carbon; b) tofal nitrogen; and c) extractable phosphorus ( 1 lag= $3 \mathrm{~m}$ ).

ple variance. However, considerable discussion exists on this topic (Bramley and White 1991). In the context of the present work, it may be admitted that the $C V$ presented in Table 1 represents approximately the actual variability of $\mathrm{OC}, \mathrm{TN}$, and extractable-P because of the large nugget variation observed in these variables.

The spatial correlation between OC and TN (Fig. 4) was calculated by an average cross-semivariogram for each area. There was a high spatial correlation between $O C$ and TN in both treatments (Fig. 5). In the ungrazed area the range of dependence was 7 lags ( $21 \mathrm{~m}$ ), with a nugget variation of $48 \%$, in the grazed treatment the range was 6 lags $(18 \mathrm{~m})$, and the nugget effect was nil. Then, whilst in the grazed area the cross-semivariogram indicated a spatial correlation between $\mathrm{OC}$ and $\mathrm{TN}$, their semivariograms 

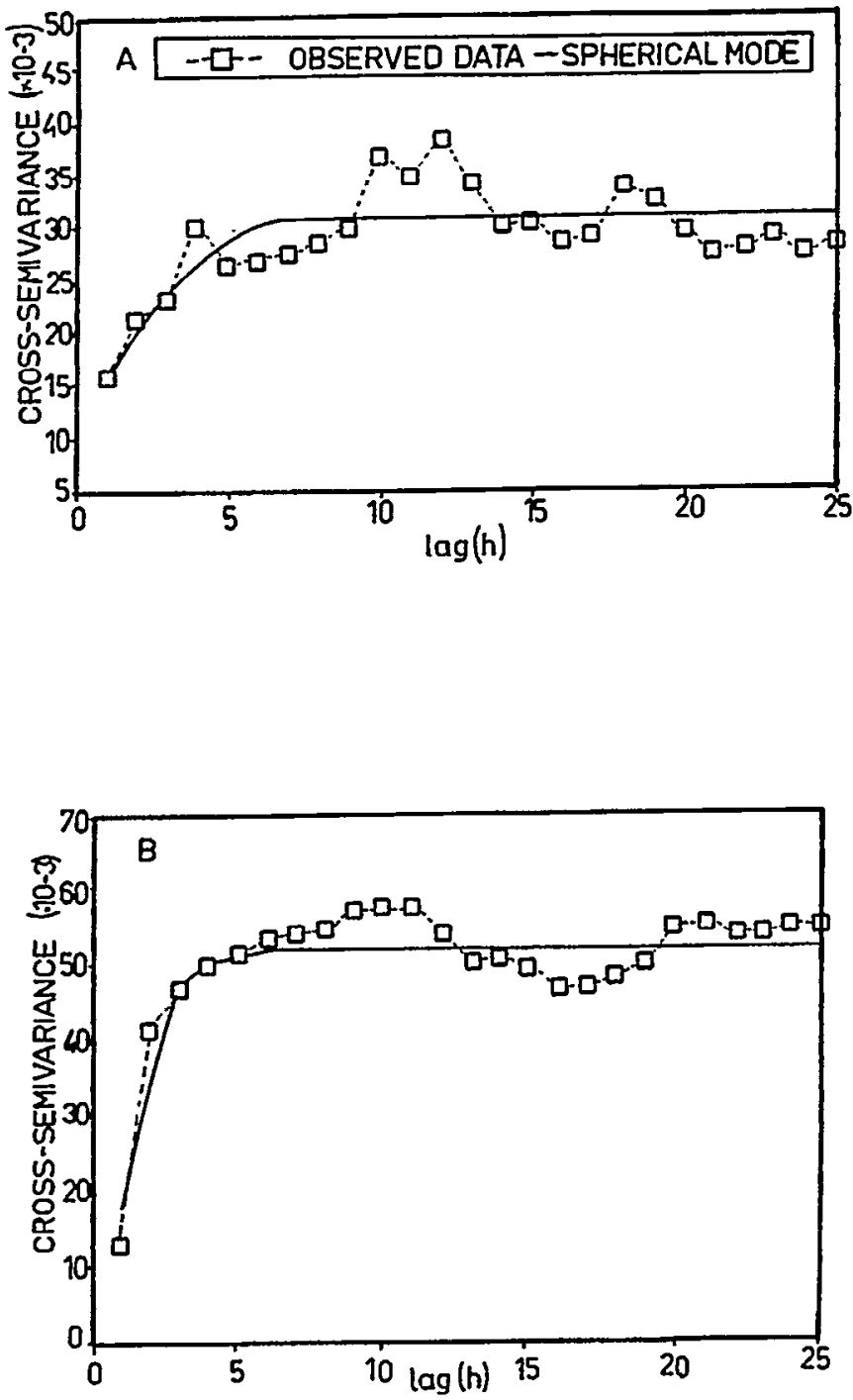

Fig. 5. Average cross-semivariogram between organic carbon and total nitrogen in a) ungrazed area and b) grazed area.

indicated pure nugget variation. Similar results were found by Vieira et al. (1983) for these soil properties. The results obtained in the grazed area differ from those of West et al. (1989). They found that the return of nutrients via animal excreta caused spatial divergence of $\mathrm{OC}$ and TN and consequently, no spatial correlation between both variables was observed. They attributed these results to the different $\mathrm{C}-\mathrm{N}$ composition of the animal excreta. Cross-semivariograms between $\mathrm{NO}_{3}-\mathrm{N}$ and $\mathrm{NH}_{4}-\mathrm{N}$ showed pure nugget variation.

\section{Discussion}

\section{Organic Carbon and Total Nitrogen.}

At the same site sampled in the present study, Chaneton et al. (1995) determined that the accumulation of soil surface litter was equal to $36.7 \mathrm{~g} \mathrm{~m}^{-2}$ in an 8 year old enclosure and $7.0 \mathrm{~g} / \mathrm{m}^{2}$ in the grazed area. Also on this study site, Sanchez (1987) observed that fungal flora degrading litter in an enclosure was more efficient than under grazing. Thus, in the ungrazed area, a higher $C$ input would be counter-balanced by a higher rate of debris decomposition.
The differences between grazed and ungrazed areas in the spatial structure of $O C$ and TN would be mainly related to changes in the grassland structure. Whilst the $\mathrm{C}$ return in the ungrazed area is spatially homogeneous because of the occurrence of litter, the patches of bare soil (around 50\%) and the uneven distribution of the scarce litter in the grazed area could induce a higher heterogeneity of the $\mathrm{C}$ returns.

Organic carbon (OC) and total nitrogen (TN) showed a similar spatial pattern in the ungrazed area, principally noted in the range of the semivariogram and the relative importance of the nugget variation. However, spatial correlation between $\mathrm{OC}$ and TN was obseved in both areas with a similar range. This fact implies that the spatial continuity of these variables is independent of the treatment. This result is a very interesting finding. Whilst the spatial distribution and amount of $\mathrm{C}$ input may induce a different spatial structure in both variables (spatial dependence in enclosure, pure nugget variation in the grazed area), it seems that the spatial correlation between them was not affected by changes in $\mathrm{C}$ input. This result suggests that the turnover of each element was affected in a similar way by grazing. From these results we assumed that in both areas there was a basic link between $\mathrm{OC}$ and TN. This could be accredited to the absence of external gains of $N$, except those provided by rainfall (Chaneton et al. 1995): neither $\mathrm{N}$-fertilization nor legumes occur in this grassland.

\section{Mineral Nitrogen}

As discussed above, the higher mineral $\mathrm{N}$ content in the enclosure on the 2 sampling dates, might partially reflect the higher biological activity in this area. In spring when the $C$ input and microbial activity is greater (Chaneton et al. 1995), litter and standing dead material check the evaporative water losses and induce a higher water content (Lavado and Taboada 1987; Sanchez 1987) in the ungrazed area which might contribute to its higher rate of $\mathrm{N}$ mineralization. The lack of any spatial structure and spatial correlation of $\mathrm{NO}_{3}-\mathrm{N}$ and $\mathrm{NH}_{4}-\mathrm{N}$ might be related to several factors affecting them at different spatial-scales (leaching, NH4 sorption, $\mathbf{N}$ inmobilization, nitrifiers inhibition, etc.). In agreement with our results, Bramley and White (1991) observed that any spatial dependence of mineral $\mathrm{N}$ is principally shortranged.

\section{Phosphorus}

The decrease of extractable-P in the grazed area (Table 1) is related to low but irreversible $P$ exportations (Chaneton et al. 1996) and the lack of P-fertilization. Annual losses of $P$ are very low but could be very important in the long run. Tests showing grasslands responses to $P$ fertilization (Ginzo et al. 1982; Lavado et al. 1993) confirm the slow losses of $P$ from the system.

The semivariogram of extractable $P$ in the ungrazed treatment deserves special consideration because of the irregularity of $g(h)$ in the first lag. This irregularity may induce serious error in the fit of the $g(h)$ data. Several workers have emphasized the importance of $\mathrm{P}$ recycling through plant debris decomposition in P-limited but unfertilized grassland soils (Blair and Boland 1978; Friesen and Blair 1988; McLaughlin et al. 1988). In this condition, the $\mathrm{P}$ released from plant residues is quickly recycled into soil inorganic P-components (Friesen and Blair 1988). Therefore, it is possible that the spatial distribution of $\mathrm{C}$ input in the grazed area induced the observed spatial dependence of extractable P. 


\section{Conclusions and Implications of Findings}

Neither treatments were replicated for estimating the effect of grazing unambiguously. However, we cautiously extended our interpretations from previous knowledge of this soils and grassland. Besides, the stock rate in the ranch, the plant community and the soil are representative of those of the region. With such limitation we were able to establish:

The spatial pattern of the 7 studied variables allowed their classification into 2 groups. The first included the variables which showed pure nugget variation, independent of the treatment and sampling date. They are $\mathrm{NO}_{3}-\mathrm{N}, \mathrm{NH}_{4}-\mathrm{N},\left(\mathrm{NO}_{3}+\mathrm{NH}_{4}\right)-\mathrm{N}$ and soil water content. The second group, the more temporal stable variables, corresponds to OC, TN, and extractable-P which had spatial structure in the ungrazed area and pure nugget variation in the grazed area. The analysis of spatial variability established the effect of grazing and detected the soil variables sensitive to grazing. Organic carbon (OC), total nitrogen (TN), and extractable $P$ presented a different pattern of spatial structure among areas. This is in agreement with the great spatial heterogeneity of vegetation found in the grassland community of the ungrazed enclosure, while in the grazing area the vegetation composition was spatially less variable.

In the present research, the apparent lack of excreta effect on the spatial variability may be attributed to the low livestock stock density in this grassland, the size of the lot $(800 \mathrm{ha})$ and the distance from the study site to the water source $(1,200 \mathrm{~m})$. All these conditions would "dilute" the effect of animal excreta in the grazed area.

After 13 years of protection from grazing significantly lower extractable-P was found in the soil of the grazed area than in the ungrazed area. This indicates a non steady-state situation for this nutrient under grazing. To achieve a sustained level of forage production from the natural vegetation, we suggest $P$ fertilization.

\section{Literature Cited}

Bauer, A., C.V. Cole, and A.L. Black. 1987. Soil property comparisons in virgin grasslands between grazed and nongrazed management systems. Soil Sci. Soc. Amer. J. 51: 176-182.

Biggar, J.W. 1978. Spatial variability of nitrogen in soils, p. 201-210. In: D.R. Nielsen and J.G. Mac Donald (Ed). Nitrogen in the environment. Academy Press. N.Y.

Blair, G.J. and O.W. Boland. 1978. The release of phosphorus from plant material added to soil. Austr. J. Soil Res. 16: 101-111.

Bramley, R.G.V. and R.E. White. 1991. An analysis of variability in the activity of nitrifiers in a soil under pasture. I. Spatially dependant variability and optimum sampling strategy. Austr. J. Soil Res. 29: 95-108.

Burkart, S.E., R.J.C. León, and C.P. Movia. 1990. Inventario fitosociologico del pastizal de la Depresión del Salado (Prov. Bs. As.) en un área representativa de sus principales ambientes. Darwiniana 30:27-69.

Chaneton, EJJ. and R.J.C. León. 1989. Heterogeneidad espacial de la comunidad en sitios pastoreados y no pastoreados en un pastizal de la Pampa deprimida. In: Proc. 1er. Congreso Latinoamericano de Ecología. Montevideo, Unuguay.

Chaneton, E.J., J.H. Lemcoff, and R.S. Lavado, 1996. Nitrogen and phosphorus cycling in grazed and ungrazed temperate subhumid grassland in Argentina. J. of Applied Ecology 33:291-302.

Clark, F.E. and E.A. Paul. 1970. The microflora of grasslands Adv. Agron. 22: 375-435.

Davidoff, B. and H.M. Selim. 1988. Correlation between spatially variable soil moisture content and soil temperature. Soil Sci. 145: 1-10.

Davidoff, B., J.W. Lewis, and H.M. Selim. 1986a. Variability of soil temperature with depth along a transect. Soil Sci. 142: 114-123.

Davidoff, B., J.W. Lewis, and H.M. Selim. 1986b. A method to verify the presence of a trend in studying spatial variability of soil temperature. Soil Sci. Soc. Amer. J. 50: 1122-1127.
Dix, R.L. 1959. Influence of grazing on the thin-soil prairie of Wisconsin. Ecol. 40: 36-49.

Dormaar, J.F., S. Smoliak, and W.D. Willms. 1989. Distribution of nitrogen fractions in grazed and ungrazed fescue grassland Ah horizon. J. Range Manage. 43: 6-9.

Facelli, J.M. and S.T.A. Pickett. 1991. Plant litter. Its dynamics and effects on plant community structure. Bot. Review. 57: 1-32.

Facelli, J.M., J.R.C. León, and V.A. Deregibus. 1989. Community structure in grazed and ungrazed grassland in the Flooding Pampa, Argentina. Amer. Midlland Nat. 121:125-133.

Friesen, D.K. and G.J. Blair. 1988. A dual radiotracer study of transformations of organic, inorganic and plant residue phosphons in soil in the presence and absence of plants. Austr. J. Soil Res. 26: 355-366.

Ginzo, H.D., M.B. Collantes, and O.M. Caso. 1982. Fertilization of a native grassland in the "Depresion del rio Salado, Province of Buenos Aires: Herbage dry matter accumulation and botanical composition. J. Range Manage. 35:35-39.

Graetz, R.D. and D.J. Tongway. 1986. Influence of grazing management on vegetation, soil structure and nutrient distribution and the infiltration of applied rainfall in a semi-arid chenopod shrubland. Austr. J. of Ecol. 1l: 347-360.

INTA. 1990. Atlas de Suelos de la Republica Argentina I, 83-202. Buenos Aires.

Johnston, A., J.F. Dormaar, and S. Smoliak. 1971. Long-term grazing effect on fescue grassland soils. J. Range Manage. 24:185-188.

Lavado R.S. and M.A. Taboada. 1985. Influencia del pastoreo sobre algunas propiedades químicas de un Natracuol de la Pampa Deprimida. Ciencia del Suelo 3:102-108.

Lavado, R.S. and M.A. Taboada. 1987. Soil salinization as an effect of grazing in a native grassland soil in the Flooding Pampa of Argentina. Soil Use \& Manage. 3: 143-148.

Lavado R.S. and M.A. Taboada. 1988. Water, salt and sodium dynamics in a Natraquoll in Argentina. Catena 15:577-594

Lavado, R.S., G. Rubio, G. Casasola, and C.R. Alvarez. 1993. Effect of waterlogging and application of nitrogen and phosphorus on the production of 2 species of an Argentine natural grassland. In: N.J. Barrow (Ed.). Development in Plant and Soil Sci., Vol. 45: 341-344. Kluwer Scientific Pub.

McLaughlin, M.J., A.M. Alston, and J.K. Martin. 1988. Phosphorus cycling in wheat-pasture rotations. II Organic phosphorus turnover and phospherous cycling. Austr. J. Soil Res. 26:343-352.

Miller, M., M. Singer, and D.R. Nielsen. 1988. Spatial variability of wheat yield and soil properties on complex Hills. Soil Sci. Soc. Amer. J. 52: 1133-1141.

Nash, M.H., L.A. Daugherty, A. Gutjahr, P.J. Wierenga, and S. Nance. 1988. Horizontal and vertical kriging of soil properties along a transect in southern New Mexico. Soil Sci. Soc. Amer J. 52: 1086-1090.

Page, A.L., R.H. Miller, and D.R. Keeney. 1982. Methods of Soil Analysis. Part 2. 2nd Ed. Wisc.

Risser, P.G., E.C. Birney, H.D. Blocker, S.W. May, J.W. Parton, and J.A. Wiens. 1981. The true prairie ecosystem. US IBP. Synthesis series 16. Hutch \& Ross Publ. Co.

Sala, O.E. 1988. The effect of herbivory on vegetation structure. p. 317-330. In: M.J.A. Werger, P.J.M. van der Aart, H.J. During, and J.T.A. Verboeren (Eds.). Plant form and vegetation structure.

Sanchez, C.P. 1987. Descomposición fúngica de la celulosa en unpastizal de la Pampa deprimida. Ciencia del Suelo 5: 135-141.

Smoliak, S., J.F. Dormaar, and A. Johnston. 1972. Long-term grazing effect on Stipa-Bouteloua prairie soils. J. Range Manage. 25:246-250.

Soriano, A. 1991. Rio de la Plata grasslands. p. 367-407. In: R.T. Coupland (Ed.). Ecosystems of the World. Volume 8 A, Nat.Grassl. Elsevier, Amsterdam.

Taboada, M.A. and R.S. Lavado. 1988. Grazing effects on soil bulk density in the Flooding Pampa of Argentina. J. of Range Manage. 41: 502-505.

Thornley, J.H.M. and E.L.J. Verberne. 1989. A model of nitrogen flows in grassland. Plant, Cell \& Environ. 12: 863-886.

Trangmar, B.B., R.S. Yost, and G. Uehara. 1985. Application of geostatistics to spatial studies of soil properties. Adv. Agron. 38: 45-94.

Vieira, S.R., J.L. Hatfield, D.R. Nielsen, and J.W. Biggar. 1983. Geostatistical theory and application to variability of some agronomical properties. Hilgardia 51: 1-75.

West, C.P., A.P. Mallarino, W.F. Wedin, and D.B. Marx. 1989. Spatial variability of soil chemical properties in grazed pastures. Soil Sci. Soc. Amer. J. 53: 784-789. 